\title{
Quaternary vegetation changes derived from a loess-like permafrost palaeosol sequence in northeast Siberia using alkane biomarker and pollen analyses
}

\author{
MICHAEL ZECH, ANDREI ANDREEV, ROLAND ZECH, STEFANIE MÜLLER, ULRICH HAMBACH, MANFRED FRECHEN
} AND WOLFGANG ZECH

BOREAS

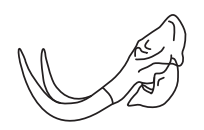

Zech, M., Andreev, A., Zech, R., Müller, S., Hambach, U., Frechen, M. \& Zech, W.: Quaternary vegetation changes derived from a loess-like permafrost palaeosol sequence in northeast Siberia using alkane biomarker and pollen analyses. Boreas, 10.1111/j.1502-3885.2009.00132.x. ISSN 0300-9483

Alkane biomarker and pollen data were obtained from a 15-m-high and probably $c$. 240-kyr-old loess-like per-
mafrost palaeosol sequence ('Tumara Palaeosol Sequence', TPS) in northeast Siberia. The alkane results were
corrected for degradation effects by applying an end-member model and were evaluated by comparing them with
the palynological results. The two data sets are generally in good agreement and suggest that the lower part of the
TPS developed mainly under larch forests, whereas the upper part of the sequence reflects the expansion of mam-
moth steppes during the Weichselian glaciation and finally reforestation during the Lateglacial and the early Ho-
locene. For the lower part of the TPS, the palaeoclimatic interpretation according to modern analogue methods
would indicate warm, interglacial conditions, but this is at odds with the climate chronostratigraphy based on a
multi-proxy palaeopedological approach and numeric dating. Provided that the correlation of the discussed stra-
tigraphic unit with the Late Saalian glaciation and the Marine Oxygen Isotope Stage 6 is correct, our results sug-
gest that temperature was not a limiting factor for tree growth at that time. Furthermore, it seems very likely that it
was not mainly temperature changes but rather increasing aridity and continentality during the course of the last
glacial that favoured the expansion of the mammoth steppe.

Michael Zech (e-mail: michael_zech@gmx.de), Chair of Geomorphology and Department of Soil Physics, University of Bayreuth, D-95440 Bayreuth, Germany; Andrei Andreev, Alfred Wegener Institute for Polar and Marine Research, Research Unit Potsdam, D-14473 Potsdam, Germany; Roland Zech, Geographical Institute, University of Bern, CH-3012 Bern, Switzerland; Stefanie Müller, Institute of Geological Science, Department of Palaeontology, Free University Berlin, D-12249 Berlin, Germany; Ulrich Hambach, Chair of Geomorphology, University of Bayreuth, D-95440 Bayreuth, Germany; Manfred Frechen, Leibniz Institute for Applied Geophysics, Geochronology and Isotope Hydrology, 30655 Hannover, Germany; Wolfgang Zech, Chair of Soil Science and Soil Geography, University of Bayreuth, D-95440 Bayreuth, Germany; received 26th January 2009, accepted 28th October 2009.
Northern Siberia may play a key role in influencing the climate of the entire Earth. The classical Milankovitch Theory suggests that changes in summer insolation owing to the Earth' orbital parameters caused a buildup of snow and ice over the extensive continental masses at high northern latitudes (Hays et al. 1976). Various positive-feedback mechanisms such as surface albedo and concentration of atmospheric carbon dioxide are considered to have then been responsible for the onsets of global glaciations. More recently, high northern latitudes have received a lot of attention as a result of the potential of their soils and peats to release large amounts of methane and carbon dioxide (Zimov et al. 2006; Khvorostyanov et al. 2008). The Siberian ecosystems may turn into significant greenhouse gas sources as global warming continues and causes melting of permafrost and mineralization of the soil organic material that has been built up and stored over thousands of years.

In order to better predict the response of ecosystems to global warming it is essential to know how they reacted to climate changes in the past. Both vegetation and climate changes in Arctic Yakutia have been reconstructed using pollen analyses (Klimanov 1984;
Klimanov \& Andreev 1992; Alekseev 1997; Tarasov et al. 1998; Andreev et al. 2001, 2002a, 2004; Ilyashuk et al. 2006 and references therein). Unfortunately, many studies of Late Pleistocene records in northern Siberia are lacking reliable age control and/or the records are not long-term continuous ones. Methodologically, palynology is limited to archives allowing conservation of pollen. Furthermore, the variable pollination rates of different plant species, the influx of pollen transported over long distances, and the different resistances of pollen taxa to degradation may cause discrepancies between local vegetation in the past and the observed pollen spectra (Fægri \& Iversen 1989). Therefore, a comparison of palynological and biogeochemical results may be useful for palaeoenvironmental reconstructions. For instance, in tropical and subtropical regions, the natural abundance of stable carbon isotopes is already widely applied to reconstruct $\mathrm{C} 3$ (trees) versus $\mathrm{C} 4$ (grasses) vegetation changes (e.g. Zech et al. 2009). In temperate, boreal and alpine environments with an exclusively $\mathrm{C} 3$ photosynthetic pathway during the Quaternary, alkane biomarker analyses could become a promising complementary method to palynology. 
Alkanes are important constituents of cuticular plant leaf waxes (Kolattukudy 1976). They are deposited with the litter and subsequently buried in soils/sediments, where they are considered to be relatively resistant to degradation (Cranwell 1981; Meyers \& Ishiwatari 1993). While short- and mid-chain alkanes serve as biomarkers for lacustrine-derived organic matter (Bourbonniere et al. 1997; Ficken et al. 2000; Zhang et al. 2004; Zech et al. 2009), long-chain alkanes $\left(\mathrm{C}_{27}, \mathrm{C}_{29}, \mathrm{C}_{31}\right.$ and $\left.\mathrm{C}_{33}\right)$ dominate in terrestrial plants. The alkane pattern thereby depends on the type of vegetation. Hence, alkanes in sediments have been used in palaeoenvironmental studies to reconstruct vegetation changes (Cranwell 1973; Farrimond \& Flanagan 1996; Nott et al. 2000; Schwark et al. 2002; Zech 2006; Zech et al. 2009).

In this paper we present alkane biomarker and pollen results obtained for a loess-like permafrost palaeosol sequence in the Tumara River Valley ('Tumara Palaeosol Sequence', TPS) in northeast Siberia. The main objectives are (i) to evaluate the potential of long-chain alkanes to serve as biomarkers in permafrost palaeosol sequences, (ii) to contribute to the reconstruction of the vegetation history in the study area, and (iii) to compare the results with the climatic chronostratigraphy based on a multi-proxy palaeopedological approach (Zech et al. 2008).

\section{Material and methods}

\section{Geographical setting, modern climate and vegetation}

The loess-like permafrost palaeosol sequence TPS $\left(120 \mathrm{~m}\right.$ a.s.l., $\left.63^{\circ} 36^{\prime} \mathrm{N}, \quad 129^{\circ} 58^{\prime} \mathrm{E}\right)$ is located about $300 \mathrm{~km}$ north of Jakutsk on the banks of the Tumara River, the latter draining part of the southern Verkhoyansk Mountains (Fig. 1). Between the mountains in the north and the debouchure into the Aldan River in the south, the Tumara River cuts a $100-\mathrm{km}$-long transect through Quaternary and Tertiary deposits. It thereby passes large moraine arcs that are abundant in the western and southwestern Verkhoyansk Forelands and that document several former piedmont glaciations (Kind 1975; Kolpakov 1979; Stauch et al. 2007). The TPS itself it situated several kilometres beyond the outermost moraine arc on a fluvioglacial terrace of Middle Pleistocene age.

Today no glaciers exist in the study area, although the climate is characterized by extremely cold winter seasons. In Jakutsk, maximum and minimum temperatures are $30^{\circ}$ to $38^{\circ} \mathrm{C}$ and $-60^{\circ}$ to $-70^{\circ} \mathrm{C}$, respectively (Müller 1980). Annual precipitation (Jakutsk: $213 \mathrm{~mm} / \mathrm{yr}$, Verkhoyansk: $155 \mathrm{~mm} / \mathrm{yr}$ ), mainly brought by the westerlies, is too low to support glacial transgression. Nevertheless, the extreme continental conditions cause the formation of permafrost 400-600 $\mathrm{m}$ thick (Wein 1999).

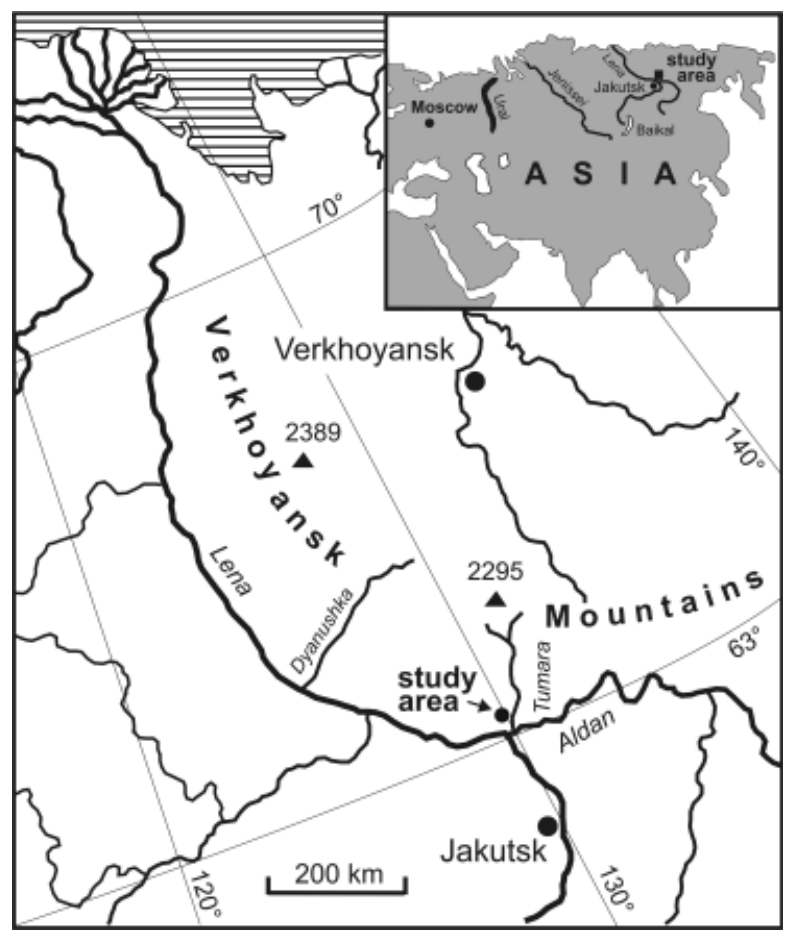

Fig. 1. Geographical setting of the Tumara Palaeosol Sequence (TPS) in the Southern Verkhoyansk Mountains, northeast Siberia.

The vegetation is characterized by larch forests that typically cover the southern and western forelands of the Verkhoyansk Mountains (Anderson \& Lozhkin 2001). According to Timofeev (2003), Larix dahurica and Betula pendula and B. alba trees are the predominant species in the forest vegetation cover. Spruce (Picea obovata) and alder (Alnus hirsuta) grow only along the rivers and creeks, where there are locally favourable micro-climatic conditions. Shrubs and dwarf shrubs including Alnus fruticosa, Betula exilis, B. fruticosa and Pinus pumila are also common in the local vegetation cover. Above c. $450 \mathrm{~m}$ a.s.l. the woodland is replaced by arctic-alpine tundra and dwarf shrub tundra communities with Pinus pumila, Betula nana, Empetrum sp., Vaccinium vitis-idaea, V. uliginosum and Ledum palustre.

\section{Stratigraphy and chronology of the TPS}

Approximately $10 \mathrm{~km}$ south of the outermost moraine arc, a $50-60 \mathrm{~m}$ high cliff is exposed on the right river bank. Its lower part consists of yellow Tertiary sand with embedded fossil woods and trunks. According to Grinenko \& Kamaletdinov (1993) the overlying grey sands and pebbles are of Early Pleistocene age. MidPleistocene fluvioglacial sandy gravels were deposited between about 15 and $33 \mathrm{~m}$ depth. The upper $15 \mathrm{~m}$ of the exposure is referred to as the 'TPS' and consists of frozen dark grey loess-like sediments interbedded with 
brown soil horizons (Fig. 2B). Only the uppermost decimetres thaw during the summer months and form the active permafrost layer. A detailed description and discussion of the chronology is provided by Zech et al. (2008), and the stable carbon and nitrogen isotope compositions are presented in Zech et al. (2007).

Briefly, both morphological features and analytical results allow the stratigraphic units $\mathrm{A}, \mathrm{B} 1-3, \mathrm{C} 1-3, \mathrm{D}$ and $\mathrm{E}$ to be distinguished. The dark grey units $\mathrm{B}, \mathrm{C} 2$ and $\mathrm{D}$ are characterized by higher organic carbon contents (TOCs) than the brown, more intensively weathered units A, C1, C2 and E (Fig. 2B). Taking into account all other available pedologic characteristics (geochemistry, grain-size distribution and characterization of the soil organic matter), it has been proposed that Units B, C2 and D reflect cold glacial conditions characterized by only thin active permafrost layers and resultant water-logging conditions (Zech et al. 2008). As a consequence, soils are not intensively weathered and organic matter is well preserved. Units A, C1, C3 and $\mathrm{E}$, on the other hand, have been interpreted to reflect interglacial or interstadial conditions (Fig. 2B). More intensive weathering and organic matter decomposition indicate better soil drainage and less influence of permafrost. Considering the available numeric dating results (Fig. 2A) and comparing the stratigraphy with other Northern Hemisphere records (e.g. Karabanov et al. 1998; Svendsen et al. 2004), a tentative correlation with marine oxygen isotope stages (MISs) has been proposed (Zech et al. 2008). Accordingly, the TPS started to develop about $240 \mathrm{kyr}$ ago. Unit D corresponds to the Late Saalian glaciation of Svendsen et al. (2004) during MIS 6, and Unit C3 to the last interglacial (Eemian) during MIS 5e. The unit boundaries $\mathrm{B} / \mathrm{C}$ and $\mathrm{C} 2 / \mathrm{C} 3$ probably reflect unconformities, and Units $\mathrm{C} 1$ and $\mathrm{C} 2$ may contain reworked material. Despite the radiocarbon age inconsistencies occurring at $1.2 \mathrm{~m}$ depth (possibly related to windblown yedoma and thus the input of old organic matter), Units B1, 2 and 3 are correlated with MIS 2, 3 and 4, respectively. This interpretation is corroborated by two new radiocarbon dates from 2.2 and $3.4 \mathrm{~m}$ depth (KIA 36491 and KIA 36490), yielding 13.1 and 40.0 cal. kyr BP for humic acids and 19.4 and $45.7 \mathrm{cal}$. kyr BP for humins, respectively (Fig. 2A).

Note that two IRSL ages in Fig. 7 of Zech et al. (2008) are plotted incorrectly (Fig. 2A). Methodologically, the IRSL data published in Zech et al. (2008) face two main problems. Insufficient bleaching prior to deposition would result in age overestimation. This may be the case for the 177-kyr date at the base of the presumably reworked Unit C2. On the other hand, IRSL age estimates extending the 100-kyr age range are often close to saturation, resulting in significant IRSL age underestimation. Furthermore, the IRSL data were not fading-corrected, as a fading correction in the exponential part of the growth curve is at present not available.

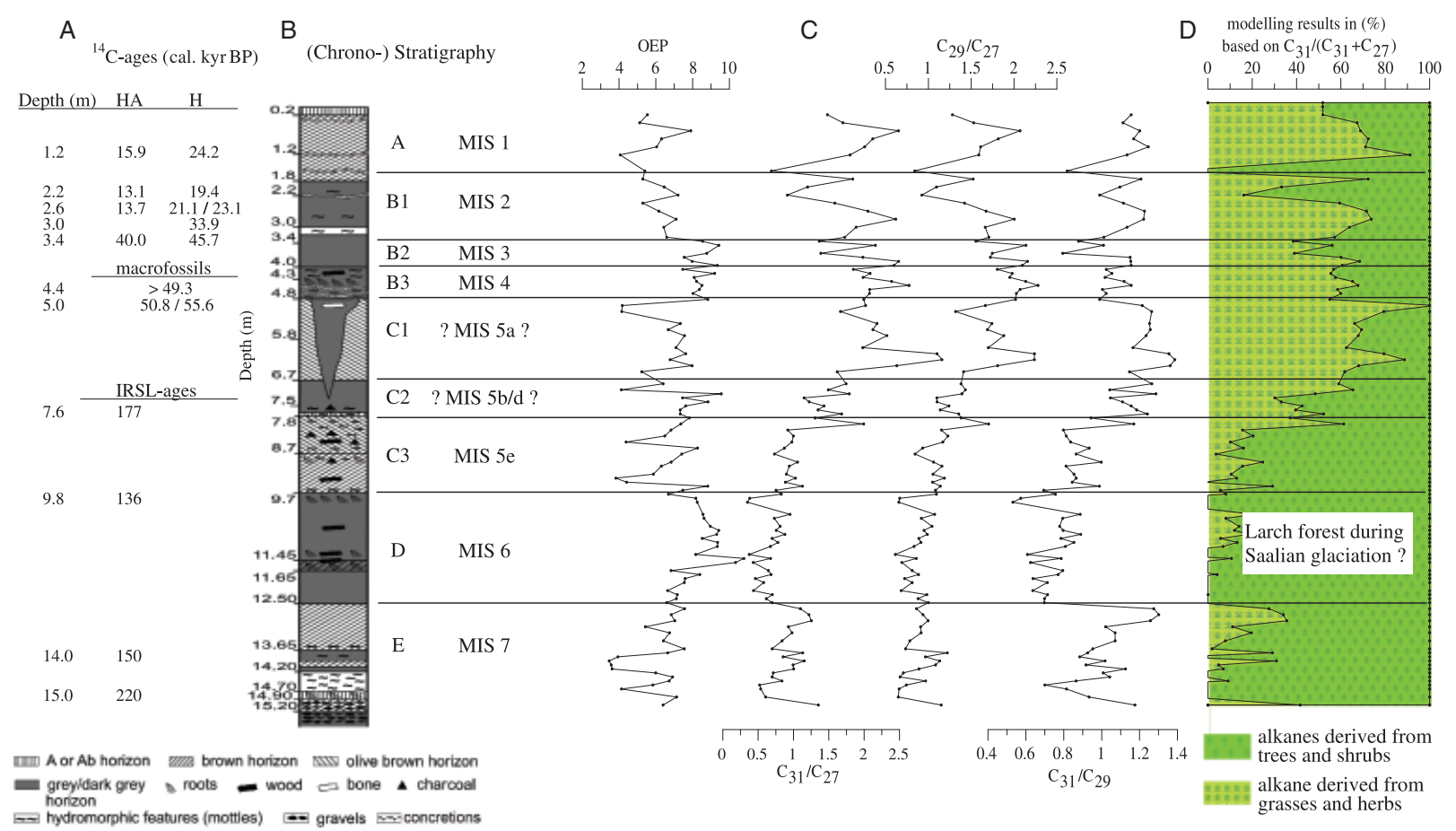

Fig. 2. A. Numerical dating results. B. Tumara Palaeosol Sequence stratigraphy and proposed chronostratigraphy according to Zech et al. (2008). C. depth profiles for the OEP (odd-over-even predominance), the alkane ratios $C_{31} / C_{27}, C_{29} / C_{27}$ and $C_{31} / C_{29}$. D. alkane biomarker modelling results. $\mathrm{HA}=$ alkali soluble substances (humic acids); $\mathrm{H}=$ alkali insoluble substances (humins). Calibration of radiocarbon ages was performed using the Calpal-Online programme. 


\section{Alkane and pollen analyses}

After the upper $15 \mathrm{~m}$ of the TPS had been cleaned and described, a total of 117 samples were taken at $10-20 \mathrm{~cm}$ intervals from the frozen deposits for geochemical and pollen analyses. The samples were airdried, sieved $(<2 \mathrm{~mm})$ and stored in plastic bags. In addition, several modern plant samples were collected for biomarker analyses.

Sample preparation of alkanes from soil and plant samples was carried out at the Institute of Soil Science and Soil Geography, University of Bayreuth. We adopted the method described by Bourbonniere et al. (1997) and Zech \& Glaser (2008): free lipids were extracted with methanol/toluene (7/3) using Soxhlet apparatuses. Concentrated lipid extracts were purified using columns filled with deactivated $(5 \%)$ silica $(2 \mathrm{~g})$ and deactivated $(5 \%)$ aluminium oxide $(2 \mathrm{~g})$. Alkanes were eluted with $45 \mathrm{ml}$ of hexane/toluene $(85 / 15)$. Quantification was performed on an HP $6890 \mathrm{GC}$ equipped with a flame ionization detector (FID). Deuterated n-alkanes $\left(\mathrm{d}_{42}-\mathrm{n}-\mathrm{C}_{20}\right.$ and $\left.\mathrm{d}_{50}-\mathrm{n}-\mathrm{C}_{24}\right)$ were added as internal and recovery standards, respectively. The odd-over-even predominance (OEP) was calculated according to the equation

$$
\begin{aligned}
\mathrm{OEP}= & \left(\mathrm{C}_{25}+\mathrm{C}_{27}+\mathrm{C}_{29}+\mathrm{C}_{31}+\mathrm{C}_{33}\right) / \\
& \left(\mathrm{C}_{26}+\mathrm{C}_{28}+\mathrm{C}_{30}+\mathrm{C}_{32}\right) .
\end{aligned}
$$

A standard hydrofluoric acid (HF) technique was used for pollen preparation (Berglund \& Ralska-Jasiewiczowa 1986). For the determination of the pollen and spore types the morphological keys of Fægri \& Iversen (1989) as well as pollen atlases (Reille 1992, 1998; Beug 2004) were used. Poorly preserved, undeterminable pollen grains were counted as Indeterminata. At least 200 pollen grains were counted in every sample, with spores tallied in addition. The mineralized conifer pollen grains were counted as reworked (ancient) Pinaceae.

Non-pollen-palynomorphs (NPPs) such as algae colonies, fungi spores, stomata and other identifiable remains were also counted and further used for the palaeoenvironmental interpretation.

According to modern analogue methods, recently applied to several pollen profiles from Arctic Russia in order to reconstruct the Late Pleistocene and Holocene climate quantitatively (Andreev \& Klimanov 2000; Andreev et al. 2003a, b, 2004), arboreal pollen indicates warm interglacial or interstadial climate conditions.

\section{Results}

\section{Alkane patterns and alkane ratios}

Total alkane concentrations in the soil samples range from 0.89 to $29.88 \mu \mathrm{g} / \mathrm{g}$ soil and from 0.10 to $2.74 \mathrm{mg} / \mathrm{g}$
TOC, respectively. In both the soil and the plant samples the long-chain alkanes ranging from $C_{25}$ to $C_{33}$ dominate and thereby reveal a strong OEP (Fig. 3). Such alkane patterns are characteristic of epicuticular plant leaf waxes (Kolattukudy 1976). The highest OEP values are typically found in fresh plants and litter (Fig. 3A, B, C, E, F). Lower OEP values and more balanced alkane patterns in soils are often explained by degradation effects (Fig. 3D, G, H) (Wiesenberg et al. 2004). OEP values for the TPS range from 3.5 to 10.8 (Fig. 2C). Maxima (OEP $\geq 8)$ generally coincide with the dark grey units B2, B3, C2 and D, indicating that the organic matter in these palaeosols is less degraded than that in other horizons of the TPS (Units A, $\mathrm{C} 1, \mathrm{C} 3$ and $\mathrm{E})$. This interpretation is corroborated by the pedological results obtained by Zech et al. (2007, 2008).

As depicted in Fig. 3A-C, the modern tree samples (e.g. needles and leaves of Larix sibirica, Betula sp. and Salix sp.) from the study area are clearly dominated by the alkane $\mathrm{C}_{27}$. This is in agreement with findings by other authors (Cranwell 1973; Nott et al. 2000; Schwark et al. 2002), who furthermore found that in grasses and herbs, in contrast, the alkanes $\mathrm{C}_{31}$ and $\mathrm{C}_{33}$ typically dominate (Fig. 3F, G). Thus, alkane ratios such as $\mathrm{C}_{31} / \mathrm{C}_{27}$ have been used in palaeoecological studies to distinguish between tree/shrub-dominated and grass/herb-dominated ecosystems. The averaged alkane pattern of Unit D can be clearly distinguished from that of Units B2 and B3, both of which have a very similar degree of degradation (mean $\mathrm{OEP}=8.4$; Fig. 3D, H). The dominance of $\mathrm{C}_{27}$ in Unit $\mathrm{D}$ indicates a mainly forested palaeoenvironment, whereas the dominance of $\mathrm{C}_{31}$ in Units B2 and B3 can be attributed to grasses and herbs having contributed significantly to the organic matter of these palaeosols. The depth profile for the ratio $\mathrm{C}_{31} / \mathrm{C}_{27}$ illustrates the respective vegetation changes semi-quantitatively for the whole TPS (Fig. 2C). Accordingly, a first severe retreat of trees and the expansion of grasses/herbs is documented in the alkane patterns of Units $\mathrm{C} 2$ and $\mathrm{C} 1$. Intensive reforestation occurred during the formation of the upper half of Unit B1.

The alkane $\mathrm{C}_{29}$ may provide additional information about past vegetation changes because Carex sp. (Cyperaceae) is dominated by $\mathrm{C}_{29}$ (Fig. 3E) and there is palynological evidence that Cyperaceae contributed significantly to the non-arboreal vegetation during the formation of the TPS. The depth profile for the $\mathrm{C}_{29} / \mathrm{C}_{27}$ ratios corroborates the tree versus grass interpretation derived from the $\mathrm{C}_{31} / \mathrm{C}_{27}$ ratios $(R=0.96$; Fig. $4 \mathrm{~B})$, but the $\mathrm{C}_{31} / \mathrm{C}_{29}$ ratios reveal distinct shifts, which can tentatively be interpreted to reflect changing contributions of Poaceae and herbs versus Cyperaceae. Accordingly, Cyperaceae dominated the non-arboreal vegetation especially during the formation of Unit D. At present, a more quantitative interpretation is challenging, because 
Fig. 3. A, B, C, E = alkane patterns of plant samples from Siberia. $\mathrm{D}=$ averaged alkane pattern over stratigraphic Unit D. F,

$\mathrm{G}=$ alkane pattern of litter and topsoil samples of grasslands in Serbia, SE Europe.

$\mathrm{H}=$ averaged alkane pattern over stratigraphic Unit B2 and B3.
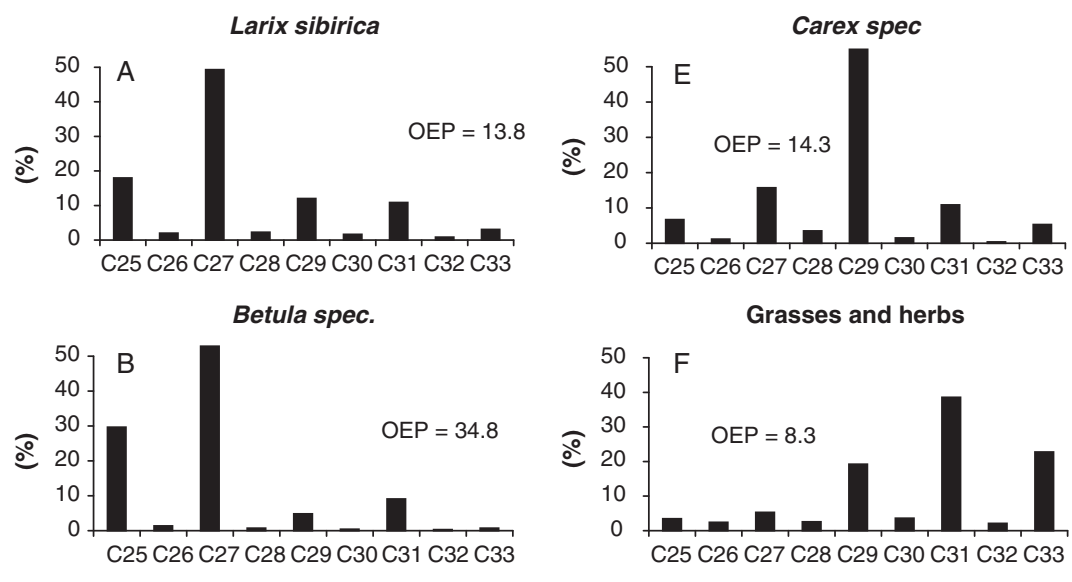

Salix spec.
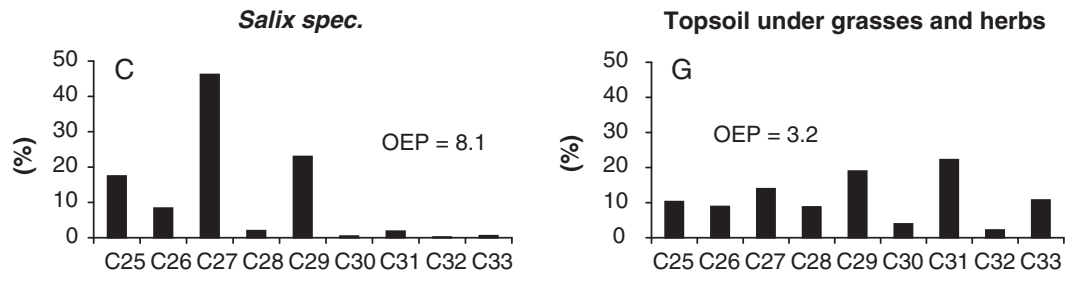

Average over Unit D

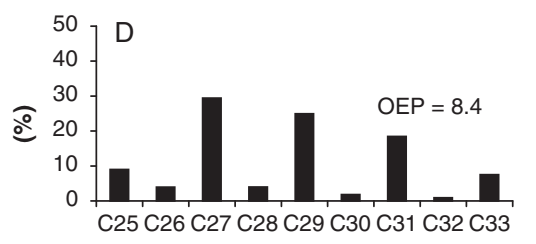

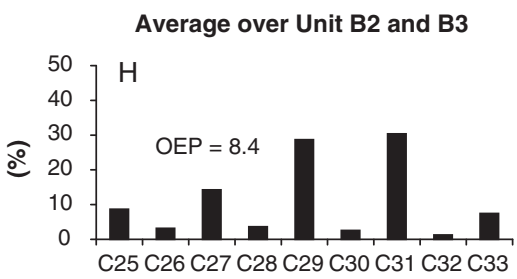

alkane rations may also change owing to degradation effects.

\section{Alkane ratio end-member modelling}

As mentioned above, the original alkane pattern of vegetation/litter is assumed to be affected by degradation processes during soil genesis, resulting in lower OEP values and more balanced alkane patterns (Fig. 3F, G). In order to address this effect more quantitatively, we recently proposed using the OEP in loess-palaeosol sequences as a proxy for the degree of degradation, and described alkane ratio degradation lines (e.g. for $\mathrm{C}_{31} /$ $\left.\left(\mathrm{C}_{31}+\mathrm{C}_{27}\right)\right)$ for natural forests and grasslands, respectively. Given that the database (in preparation) for Siberian modern plants and soils is still very small but generally in agreement with the published database, we adopted the degradation lines of Zech et al. (in press) to process the alkane results from the TPS. Using these degradation lines in an end-member model allows one to estimate the percentage contribution of alkanes derived from trees and shrubs versus that derived from grasses and herbs (Fig. 2D). For methodological details the reader is referred to the literature.

Basically, the modelling results confirm the interpretation inferred from the alkane ratios alone. Results for $\mathrm{C}_{31} /\left(\mathrm{C}_{31}+\mathrm{C}_{27}\right)$ are shown in Fig. $2 \mathrm{D}$ and corroborate the finding that the lower part of the TPS contains mainly alkanes derived from trees and shrubs, whereas the contribution of grasses and herbs is more than $50 \%$ in the upper part of the TPS. Reforestation is documented in the upper part of Unit B1.

\section{Palynological results}

The studied pollen spectra can be subdivided into sixteen pollen zones (PZ) (Fig. 4) as follows.

- Pollen of Cyperaceae and Poaceae predominate in the lowermost PZ-I (14.7-15.2 $\mathrm{m}$ depth). The pollen concentration is high. Open sedge-grass communities probably covered the study area. The pollen assemblages may point to interstadial climatic conditions.

- PZ-II (13.9-14.7 m depth) contains very few pollen grains. The absence of palynomorphs could be the result of intensive pollen degradation during the sedimentation, and this zone cannot be used for a palaeoenvironmental interpretation.

- PZ-III (13.1-13.9 m depth) is dominated by Cyperaceae pollen with a few grains of Poaceae, Picea, Pinus s/g Haploxylon and Sphagnum spores. There 


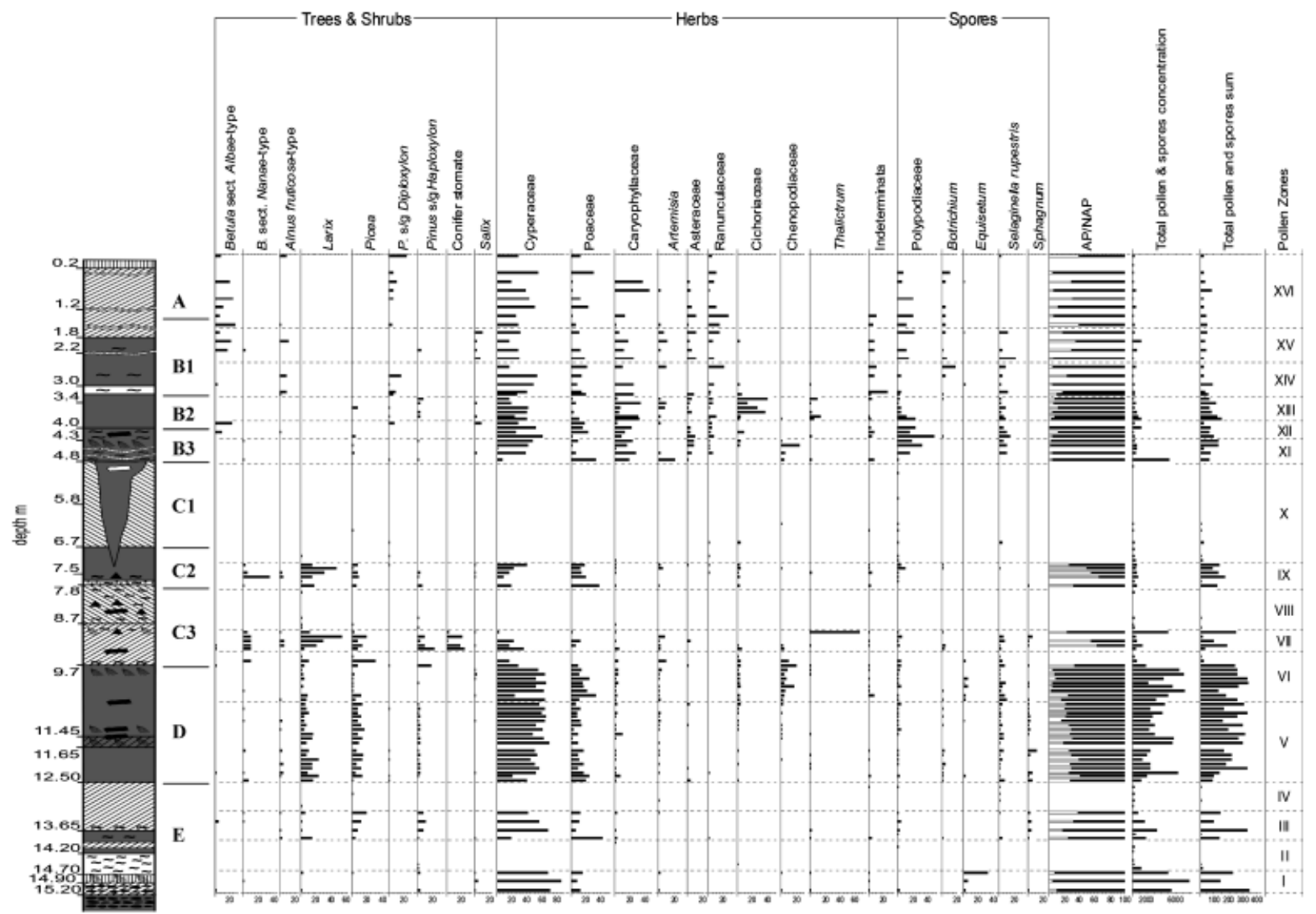

Fig. 4. Pollen percentage diagram of the Tumara Palaeosol Sequence.

are also a few pollen of Larix. Pollen concentration is rather high. Larch-spruce forest probably dominated the area. Relatively high amounts of Pinus s/g Haploxylon pollen may indicate that Siberian pine (Pinus sibirica) was the co-dominant tree taxon; however, the pollen might have been partly or completely produced by Siberian dwarf pine (Pinus pumila). In this case, Siberian dwarf pine was (co-) dominant. Wet habitats with Cyperaceae and Sphagnum were also common in the study area. The PZ-III pollen assemblages point to interglacial environmental conditions.

- PZ-IV (12.5-13.1 m depth) contains very few pollen grains and cannot be used for a palaeoenvironmental interpretation.

- PZ-V (10.5-12.5 m depth) is dominated mostly by Cyperaceae pollen. Poaceae, Larix and Picea are also abundant. Pollen concentration is rather high. The lower subzone reveals the presence of Ericales and higher amounts of Sphagnum spores, whereas the upper subzone contains higher amounts of $\mathrm{Ci}$ choriaceae, Asteraceae and Chenopodiaceae. Larch and spruce trees dominated the area. Wet habitats with Cyperaceae and Sphagnum were also common. According to the modern analogue methods, these pollen assemblages reflect interglacial environmental conditions with a slight deterioration in the upper subzone.

- The amount of tree pollen significantly decreases in PZ-VI (9.4-10.5 m. depth), whereas pollen of Poaceae, Caryophyllaceae and especially Chenopodiaceae increases. However, pollen of Larix is still present. This may point to a climatic deterioration at the end of the preceding interglacial or to a colder episode within the interglacial.

- Rather high amounts of pollen from Larix, Picea, Pinus s/g Haploxylon and Betula sect Albae as well as coniferous stomata characterize PZ-VII (8.9-9.4 m depth). Larch forest with spruce and tree birch and probably Siberian pine dominated the area. Pollen assemblages reflect an interglacial environment.

- PZ-VIII (7.9-8.9 m depth) contains very few pollen grains and cannot be used for a palaeoenvironmental interpretation.

- PZ-IX (7.1-7.9 m depth) is dominated mostly by pollen of Larix, Cyperaceae and Poaceae, with a few Picea and Polypodiaceae spores. The pollen concentration is rather low. The spectra indicate that larch forest with a few spruce dominated the 
area, indicating an interglacial environment according to modern analogue methods.

- PZ-X (4.9-7.1 m depth) contains very few palynomorphs (mostly Poaceae and Polypodiaceae) and cannot be used for a palaeoenvironmental interpretation.

- Pollen of Cyperaceae, Caryophyllaceae, and Poaceae with Polypodiaceae and Glomus spores dominates in PZ-XI (4.3-4.9 m depth). Treeless steppelike glacial communities probably covered the study area during the formation of this palaeosol.

- PZ-XII (3.9-4.3 m depth) differs from PZ-XI by rather high amounts of Betula sect Albae and Salix. This can be interpreted as climatic amelioration.

- Pollen of Chenopodiaceae and other herbs as well as Glomus spores make a large contribution to the PZ-XIII spectra (3.3-3.9 m depth). A few Picea, Pinus and Salix pollen are also present. Although the former ones in particular could represent long-distance transport, this could point to interstadial conditions.

- Pinus together with a few Alnus pollen is also present in PZ-XIV (2.5-3.3 $\mathrm{m}$ depth). However, the dominance of pollen from grasses and herbs indicates glacial conditions.

- The amounts of both Betula and Salix pollen increase significantly in the pollen assemblages of PZ-XV (1.6-2.5 $\mathrm{m}$ depth). Although the pollen concentration remains low, this reflects a climatic amelioration at the end of a glacial and thus can be correlated with the Lateglacial period.

- PZ-XVI (0-1.6m depth) is characterized by the permanent presence of Betula and the appearance of Pinus sylvestris in the upper subzone. This latter finding can be correlated with the occurrence of pine in Central Yakutia about $6 \mathrm{kyr}$ ago (e.g. Andreev et al. 1997, and references therein). Again, the pollen concentration is relatively low. We assume that this uppermost pollen zone developed during the Holocene, when the study area was covered mostly by larch forests as nowadays. However, Lar$i x$ pollen is easily destroyed in well-aerated topsoils.

In the following we will use the palynological evidence in order to evaluate the alkane biomarker method and to infer palaeoclimatic implications from the palaeobotanic results.

\section{Discussion}

\section{Comparison of the alkane biomarker and pollen results and palaeoclimatic implications}

Both methods applied to the TPS for the reconstruction of vegetation changes have their advantages and dis- advantages (Fægri \& Iversen 1989; Farrimond \& Flanagan 1996; Ficken et al. 1998). The comparison between the biomarker and the pollen results shows that the two data sets are generally in good agreement (Figs 2D, 4). First, this confirms the applicability of the alkane ratio end-member model proposed by Zech et al. (in press) to northeast Siberian ecosystems. Second, given the premise that trees and shrubs versus grasses and herbs can be directly interpreted in terms of warm versus cold (modern analogue methods), the following palaeoclimatic conditions can be reconstructed.

Unit $\mathrm{E}$ is characterized mainly by tree-derived alkanes in the lower part and by an increasing contribution of grass-derived alkanes in the upper part (Fig. $2 \mathrm{D})$. The alkane ratio $\mathrm{C}_{31} / \mathrm{C}_{29}$ suggests that this is attributable mainly to Poaceae and herbs and not to $\mathrm{Cy}$ peraceae. This interpretation is corroborated by the presence of Larix, Picea and Pinus pollen and by a maximum of Poaceae pollen. The inferred warm interglacial conditions are in agreement with the palaeopedologic findings and suggest, in combination with the numeric data, a correlation of Unit E with MIS 7.

Larix pollen, assemblaged with pollen from Picea and Pinus, is also very abundant in Unit D (Fig. 4). Although Cyperaceae and Poaceae pollen are abundant too, the alkane modelling results suggest that most of the alkanes in this unit originate from trees (Fig. 2D). Possibly, the grass pollen does not reflect the dominant standing vegetation but mainly short- and middledistance transported pollen. According to modern analogue methods, Unit D developed during interglacial conditions under larch forest. This is clearly at odds with the palaeopedologic results and their glacial versus interglacial interpretation by Zech et al. (2008). The first significant spreading of herbs (Caryophyllaceae, Cichoriaceae and Chenopodiaceae) in the upper part of Unit D (Fig. 4) is accompanied by about a $20 \%$ contribution of non-arboreal alkanes (Fig. 2D), indicating a slight climatic deterioration or habitat disturbance.

Pollen grains are preserved only to some extent in the middle part of the TPS (Unit C, Fig. 4). This corroborates the palaeopedologic finding that Units $\mathrm{C} 1$ and $\mathrm{C} 2$ may be composed of reworked material and that the palaeosols of Unit $\mathrm{C} 3$ are intensively degraded and mineralized (Fig 2). The extraordinarily high AP/NAP ratios of PZ-VII and IX in Units $\mathrm{C} 3$ and $\mathrm{C} 2$ are especially confirmed by the alkane results of Unit $\mathrm{C} 3$, the latter being correlated with the Last Interglacial (sensu stricto), whereas tree-derived alkanes decrease dramatically at the transitions to $\mathrm{C} 2$ and again to $\mathrm{C} 1$ (Fig 4C). The reconstructed vegetation changes reflect severe climatic deterioration during the Early Weichselian glaciation.

Both biomarker and pollen results show that herbs made a large contribution to the vegetation cover in the upper part of the TPS (Unit A and B, Figs 2D, 4). 
Significant reforestation occurred only in the middle of Unit B1. This is documented both by the abundance of tree-derived alkanes and by the marked increase of $\mathrm{Be}$ tula, Albae and Salix pollen, and probably reflects the Bölling/Alleröd and the Boreal warming (Andreev et al. 1997, 2002b; Lozhkin et al. 2007). One may also speculate that the modest increase of the tree-derived alkanes in Unit B2 and the abrupt increase of grassderived alkanes at $1.9 \mathrm{~m}$ depth correspond to the MIS 3 Kargin Interstadial and the Younger Dryas event, respectively. The suggested MIS 3 interstadial is confirmed by Betula and Salix pollen in Unit B2, whereas the adjacent occurrence of Pinus pollen probably reflects long-distance transport because Pinus sylvestris is assumed to have come to Central Yakutia not before c. $6 \mathrm{kyr}$ BP (Andreev et al. 1997, and references therein) and is easily windblown.

Unit A contains pollen from trees, grasses and herbs. In particular, pollen from Betula and Pinus sylvestris is fairly abundant, the latter being characteristic for Holocene pollen spectra in Central Yakutia. Although Larix pollen should be fairly abundant in Unit A too, it is missing here. This discrepancy is often observed in recent pollen spectra under larch forests and is attributed to the poor preservation of larch pollen in soils (e.g. Andreev et al. 2001). However, Unit A is also characterized by an unexpectedly low contribution of tree-derived alkanes. This may partly be a result of climatic deterioration in Siberia since about $5 \mathrm{kyr}$ BP (Andreev et al. 2001; Popp et al. 2006; Tarasov et al. 2009). We assume, however, that it is mainly a very local phenomenon caused by the approaching cliff edge (exposure to wind and soil drainage) influencing only the standing vegetation at the sampling site.

Summarizing, the biomarker- and pollen-based vegetation history is only partly in agreement with the chronostratigraphy proposed by Zech et al. (2008) for the TPS. In particular, they seems to be at odds in Unit $\mathrm{D}$, where we find evidence for larch forests, but the palaeopedologic features and the numeric data suggest correlating this unit with the Saalian glaciation during MIS 6.

\section{Warm plant taxa during cold glacial periods?}

Establishing chronostratigraphies for sediment records is certainly one of the most important but often also one of the most challenging aims in Quaternary research. Apart from numeric dating methods (mainly luminescence and radiocarbon dating) and marker horizons (tephra layers and palaeomagnetic events), many studies focussing on terrestrial archives use climatically controlled proxies such as magnetic susceptibility and geophysical and geochemical parameters to derive climate stratigraphies that are then tuned to orbital parameters or existing climate stratigraphies (e.g.
Chlachula et al. 1997; Karabanov et al. 1998; Heslop et al. 2000; Bronger 2003; Evans et al. 2003; Buggle et al. 2009).

Major problems may arise when numeric dating results are inconsistent or sediment ages approach the methodologically possible dating limits. This holds true for many of the numeric dating results obtained for the TPS (Fig. 2A) and hampers the establishment of a precise chronostratigraphy based on numeric dating results alone. We have therefore recently proposed a climate stratigraphy for the TPS based on a multiproxy pedological approach and correlated it with the glacial history of northeast Siberia (Svendsen et al. 2004) and the regional geomorphological and Quaternary stratigraphic scheme (Grinenko \& Kamaletdinov 1993).

Furthermore, it may happen that different proxies suggest different climate stratigraphies and hence also different chronostratigraphies. In the case of the TPS, the pedologic parameters and the results from numeric dating suggest correlating Unit D with the Saalian glaciation during MIS 6, whereas the vegetation reconstruction indicates warm plant taxa (trees). Interestingly, the TPS is not the only record in the study area for which the vegetation history contradicts the reconstructed climate history based on other methods. In 2007, a special publication was dedicated to the El'gygytgyn Crater Lake (Brigham-Grette et al. 2007). Although these lake sediments certainly represent the best possible palaeoenvironmental archive for northeast Siberia, Lozhkin et al. (2007) present a different chronology based on palynological results from those of Nowaczyk et al. (2007) and Melles et al. (2007) based on numeric dating, geochemical and magnetic susceptibility results. Lozhkin et al. (2007) emphasize that otherwise warm plant taxa would have persisted under cool climates and vice versa.

First, however, there is increasing evidence supporting exactly this apparent contradiction. Müller et al. (2009), for instance, report the constant presence of Larix pollen in lake sediments of the Verkhoyansk Mountains during the last glaciations, and Werner et al. (2009) found evidence for larch presence during the Younger Dryas. A recently published macrofossil database for woody taxa confirms these findings (Binney et al. 2009). Hence, forests have continued to prevail at least regionally in refugium areas (e.g. Anderson \& Lozhkin 2001; Brubaker et al. 2005; Sher et al. 2005) even in this extremely continental part of the Northern Hemisphere, with winter temperatures dropping down to $-70^{\circ} \mathrm{C}$ in winter. The same holds true for other periglacial areas such as the Carpathian Basin in southeast Europe (Willis \& Andel 2004; Zech et al. in press).

Secondly, a more differentiated view of climate parameters than just warm versus cold may contribute to a distrust of the paradigm of larch forests prevailing only during interglacials. We suggest that besides 
changes in temperature more focus should be put on changes in precipitation and seasonality when interpreting the vegetation history of northeast Siberia. A tremendous increase in aridity during the last two glacial cycles is well documented by the extraordinarily extensive Late Saalian glaciation and then progressively smaller northern and northeastern Siberian Weichselian ice sheets and glaciers (Svendsen et al. 2004; Stauch \& Gualtieri 2008; W. Zech, R. Zech, M. Zech, K. Leiber, M. Dippold, M. Frechen, R. Bussert \& A. Andreev, submitted). Consequently, provided that the chronostratigraphy for the TPS is correct and Unit D corresponds to MIS 6 and the Late Saalian glaciation, we suggest not only that precipitation was relatively high: also, the summer temperatures in the study area were not extremely low and allowed the persistence of larch forests. There is abundant evidence that the subsequent interglacial (MIS 5) was also anomalously warm, with summer temperatures possibly more than $10^{\circ}$ higher than they are today (Cape - Last Interglacial Project Members 2006; Kienast et al. 2008). It was not utill then that forests were largely replaced by mammoth steppes. Kienast et al. (2005) suggested that this might not necessarily be the result of lower summer temperatures, but of progressively increasing aridity. They reconstructed relatively warm summers during the last cold stage and explained this with extreme continental climate conditions and strong temperature seasonality. Trees grew only on favourable sites, where for instance snow cover was sufficient despite the extreme aridity to protect the plants during the cold winter season. With climate amelioration during the Lateglacial, the marine transgression and the rising oceanic influence (reduced continentality), the glacial mammoth steppes were replaced by taiga forests in the south, and by wetland tundras in the north. In the wetland tundras today, the growth of trees might be inhibited primarily by paludification and the limited availability of well-drained sites rather than by temperature (Crawford et al. 2003; Lloyd et al. 2003).

\section{Conclusions}

Alkane biomarker and pollen results for the TPS were presented in order (i) to evaluate the potential of longchain alkanes to serve as biomarkers in permafrost palaeosol sequences, (ii) to contribute to the reconstruction of the vegetation history in the study area, and (iii) to compare the results with the climatic chronostratigraphy, which is based on a multi-proxy palaeopedological approach (Zech et al. 2008).

- The alkane patterns vary significantly with depth, suggesting that major vegetation changes are re- corded in the palaeosol sequence. Whereas high $\mathrm{C}_{31} / \mathrm{C}_{27}$ ratios are characteristic for grasses and herbs, the dominance of $\mathrm{C}_{27}$ is characteristic for trees and shrubs.

- As the alkane ratios in the palaeosols do not depend only on the former standing vegetation but also on the degree of organic matter degradation, a recently proposed end-member model (Zech et al. in press) was applied to the alkane results from the TPS. This enables also a more quantitative palaeovegetation reconstruction.

- The good agreement between results from alkane biomarker and pollen analyses is promising, particularly with regard to the fact that alkanes can also be obtained from palaeosols, in which pollen is too degraded to infer palaeoclimatic information.

- According to modern analogue methods: (i) the tree dominance and especially the occurrence of Larix pollen in the lower part of the TPS would traditionally have to be interpreted in terms of warm interglacial conditions, (ii) the grass and herb dominance in the upper part of the TPS reflects cold glacial conditions corresponding to the Weichselian glaciation during MIS 2 and 4, and (iii) the reforestation occurring at about $2.5 \mathrm{~m}$ depth indicates the Lateglacial climatic amelioration and early Holocene climate optimum.

- However, the traditional interpretation of larch forests, reconstructed also for Unit D, conflicts with the chronostratigraphy derived from a multiproxy palaeopedologic approach and numeric dating (Zech et al. 2008). Provided that the correlation of Unit D with MIS 6 is correct, we suggest that temperature was not a limiting factor for tree growth during the Saalian glaciation, and that strong continentality and increasingly more arid conditions since the onset of the last glacial cycle limited tree growth and favoured the establishment of the mammoth steppes in northeast Siberia.

Acknowledgements. - Fieldwork was carried out in collaboration with scientists from the following Russian and German Institutes: Diamond and Precious Metal Geology Institute, Yakutsk; Siberian Branch of the Russian Academy of Sciences, Yakutsk; Permafrost Institute, Yakutsk; Geographical Institute, University of Aachen; Alfred Wegener Institute, Potsdam. Logistical support was provided by C. Siegert (AWI Potsdam) and Innokentiy Belolyubsky (Yakutsk). Radiocarbon dating was conducted at the Leibniz Laboratory, Kiel, Germany, and calibration was performed with the Calpal-Online programme. The study was funded by the German Research Foundation (ZE 154/52). We would like to thank A. Bräuning, B. Buggle, M. Fuchs and K. Leiber for intensive discussions, and K. Jeschke, M. Haider, I. Thaufelder, T. Gonter and A. Mergner for support during laboratory work. We appreciate the useful comments of K. Kremenetski, J.A. Piotrowski and an anonymous reviewer on an earlier version of the manuscript. M. Zech also gratefully acknowledges the support given by the Alexander von HumboldtFoundation. 


\section{References}

Alekseev, M. N. 1997: Palaeogeography and geochronology in the Russian Eastern Arctic during the second half of the Quaternary. Quaternary International 41/42, 11-15.

Anderson, P. M. \& Lozhkin, A. V. 2001: The Stage 3 interstadial complex (Karginskii/middle Wisconsinan interval) of Beringia: variations in paleoenvironments and implications for paleoclimatic interpretations. Quaternary Science Reviews 20, 93-125.

Andreev, A. A. \& Klimanov, V. A. 2000: Quantitative Holocene climatic reconstruction from Arctic Russia. Journal of Paleolimnology 24, 81-91.

Andreev, A. A., Grosse, G., Schirrmeister, L., Kuzmina, S. A., Novenko, E. Y., Bobrov, A. A., Tarasov, P. E., Ilyashuk, B. P., Kuznetsova, T. V., Krbetschek, M., Meyer, H. \& Kunitsky, V. V. 2004: Late Saalian and Eemian palaeoenvironmental history of the Bol'shoy Lyakhovsky Island (Laptev Sea region, Arctic Siberia). Boreas 33, 319-348.

Andreev, A. A., Klimanov, V. A. \& Sulerzhitsky, L. D. 1997: Younger Dryas pollen records from central and southern Yakutia. Quaternary International 41/42, 111-117.

Andreev, A. A., Klimanov, V. A. \& Sulerzhitsky, L. D. 2001: Vegetation and climate history of the Yana River lowland, Russia, during the last 6400 yr. Quaternary Science Reviews 20, 259-266.

Andreev, A. A., Schirrmeister, L., Siegert, C., Bobrov, A. A., Demske, D., Seiffert, M. \& Hubberten, H.-W. 2002a: Palaeoenvironmental changes in northeastern Siberia during the Upper Quaternary - evidence from pollen records of the Bykovsky Peninsula. Polarforschung 70, 13-25.

Andreev, A. A., Siegert, C., Klimanov, V. A., Derevyagin, A. Y., Shilova, G. N. \& Melles, M. 2002b: Late Pleistocene and Holocene vegetation and climate on the Taymyr Lowland, Northern Siberia. Quaternary Research 57, 138-150.

Andreev, A. A., Tarasov, P. E., Klimanov, V. A. \& Hubberten, H.-W. 2003a: Russian Arctic lakes as climatic archives: pollen-based reconstructions of the Late Quaternary climate. Terra Nostra 6, $17-21$.

Andreev, A. A., Tarasov, P. E., Siegert, C., Ebel, T., Klimanov, V. A., Melles, M., Bobrov, A. A., Dereviagin, A. Y., Lubinski, D. \& Hubberten, H.-W. 2003b: Vegetation and climate changes on the northern Taymyr, Russia during the Upper Pleistocene and Holocene reconstructed from pollen records. Boreas 32, 484-505.

Berglund, B. \& Ralska-Jasiewiczowa, M. 1986: Pollen analysis and pollen diagrams. In Berglund, B. (ed.): Handbook of Holocene Palaeoecology and Palaeohydrology, 455-484. Interscience, New York.

Beug, H. 2004: Leitfaden der Pollenbestimmung für Mitteleuropa und angrenzende Gebiete. 542 pp. Verlag Dr. Friedrich Pfeil, Munich.

Binney, H. A., Willis, K. J., Edwards, M. E., Bhagwat, S. A., Anderson, P. M., Andreev, A. A., Blaauw, M., Damblon, F., Haesaerts, P., Kienast, F., Kremenetski, K. V., Krivonogov, S. K., Lozhkin, A., MacDonald, G., Novenko, E. Y., Oksanen, P., Sapelko, T. V., Valiranta, M. \& Vazhenina, L. 2009: The distribution of lateQuaternary woody taxa in northern Eurasia: evidence from a new macrofossil database. Quaternary Science Reviews 28, 2445-2464.

Bourbonniere, R. A., Telford, S. L., Ziolkowski, L. A., Lee, J., Evans, M. S. \& Meyers, P. A. 1997: Biogeochemical marker profiles in cores of dated sediments from large North American lakes. In Eganhouse, R. P. (ed): Molecular Markers in Environmental Geochemistry, ACS Symposium Series, 133-150. American Chemical Society, Washington, DC.

Brigham-Grette, J., Melles, M., Minyuk, P. \& Scientific Party 2007: Overview and significance of a 250 ka paleoclimate record from El'gygytgyn Crater Lake, NE Russia. Journal of Paleolimnology 37, $1-16$.

Bronger, A. 2003: Correlation of loess-paleosol sequences in East and Central Asia with SE Central Europe: towards a continental Quaternary pedostratigraphy and paleoclimatic history. Quaternary International 106-107, 11-31.

Brubaker, L. B., Anderson, P. M., Edwards, M. E. \& Lozhkin, A. V. 2005: Beringia as a glacial refugium for boreal trees and shrubs: new perspectives from mapped pollen data. Journal of Biogeography 32, 833-848.

Buggle, B., Hambach, U., Glaser, B., Gerasimenko, N., Markovic, S., Glaser, I. \& Zöller, L. 2009: Stratigraphy, and spatial and temporal paleoclimatic trends in Southeastern/Eastern European loess-paleosol sequences. Quaternary International 196, 86-106.

Cape - Last Interglacial Project Members 2006: Last Interglacial Arctic warmth confirms polar amplification of climate change. Quaternary Science Reviews 25, 1383-1400.

Chlachula, J., Rutter, N. W. \& Evans, M. E. 1997: A late Quaternary loess-palaeosol record at Kurtak, Southern Siberia. Canadian Journal of Earth Sciences 34, 679-686.

Cranwell, P. A. 1973: Chain-length distribution of n-alkanes from lake sediments in relation to post-glacial environmental change. Freshwater Biology 3, 259-265.

Cranwell, P. A. 1981: Diagenesis of free and bound lipids in terrestrial detritus deposits in a lacustrine sediment. Organic Geochemistry 3, $79-89$.

Crawford, R., Jeffree, C. \& Rees, W. 2003: Paludification and forest retreat in northern oceanic environments. Annals of Botany 91, 213-226.

Evans, M. E., Rutter, N. W., Catto, N., Chlachula, J. \& Nyvlt, D. 2003: Magnetoclimatology: Teleconnection between the Siberian loess record and North Atlantic Heinrich events. Geology 31, 537-540.

Fægri, K. \& Iversen, J. 1989: Textbook of Pollen Analysis. 328 pp. John Wiley \& Sons, Chichester.

Farrimond, P. \& Flanagan, R. L. 1996: Lipid stratigraphy of a Flandrian peat bed (Northumberland, UK): comparison with the pollen record. The Holocene 6, 67-74.

Ficken, K. J., Barber, K. E. \& Eglinton, G. 1998: Lipid biomarker, $\delta^{13} \mathrm{C}$ and plant macrofossil stratigraphy of a Scottish montane peat bog over the last two millennia. Organic Geochemistry 28, 217-237.

Ficken, K. J., Li, B., Swain, D. L. \& Eglinton, G. 2000: An n-alkane proxy for the sedimentary input of submerged/floating freshwater aquatic macrophytes. Organic Geochemistry 31, 745-749.

Grinenko, V. S. \& Kamaletdinov, V. A. 1993: Geological map of Yakutia. VSEGEI, St. Petersburg (in Russian).

Hays, J., Imbrie, J. \& Shackleton, N. 1976: Variations in the Earth's orbit: Pacemaker of the Ice Ages. Science 194, 1121-1132.

Heslop, D., Langereis, C. G. \& Dekkers, M. J. 2000: A new astronomical timescale for the loess deposits of Northern China. Earth and Planetary Science Letters 184, 125-139.

Ilyashuk, B. P., Andreev, A. A., Bobrov, A. A., Tumskoy, V. E. \& Ilyashuk, E. A. 2006: Interglacial history of a palaeo-lake and regional environment: a multi-proxy study of a permafrost deposit from Bol'shoy Lyakhovsky Island, Arctic Siberia. Journal of Paleolimnology 35, 855-872.

Karabanov, E. B., Prokopenko, A. A., Williams, D. F. \& Colman, S. M. 1998: Evidence from Lake Baikal for Siberian Glaciation during Oxygen-Isotope Substage 5d. Quaternary Research 50, 46-55.

Khvorostyanov, D., Ciais, P., Krinner, G. \& Zimov, S. 2008: Vulnerability of east Siberia's frozen carbon stores to future warming. Geophysical Research Letters 35, 1073, doi:10.1029/2008GL033639.

Kienast, F., Schirrmeister, L., Siegert, C. \& Tarasov, P. 2005: Palaeobotanical evidence for warm summers in the East Siberian Arctic during the last cold stage. Quaternary Research 63, 283-300.

Kienast, F., Tarasov, P., Schirrmeister, L., Grosse, G. \& Andreev, A. 2008: Continental climate in the East Siberian Arctic during the last interglacial: Implications from palaeobotanical records. Global and Planetary Change 60, 535-562.

Kind, N. V. 1975: Glaciations in the Verkhoyansk Mountains and their place in the radiocarbon geochronology of the Siberian Late Anthropogene. Biuletyn Peryglacjalny 2, 41-54.

Klimanov, V. A. 1984: Paleoclimatic reconstruction based on the information-statistical method. In Velichko, A. A., Wright, J. E. \& Barnosky, C. W. (eds.): Late Quaternary Environments of the Soviet Union, 297-303. University of Minnesota Press, Minneapolis.

Klimanov, V. A. \& Andreev, A. A. 1992: Correlation analysis of surface pollen spectra from Yakutia. Izvestiya Akademii Nauk USSR, Seria Geograficheskaya 5, 82-93 (in Russian). 
Kolattukudy, P. E. 1976: Biochemistry of plant waxes. In Kolattukudy, P. E. (ed.): Chemistry and Biochemistry of Natural Waxes, 290-349. Elsevier, Amsterdam.

Kolpakov, V. V. 1979: Glacial and periglacial topography of the Verkhoyansk glacial area and new radiocarbon dates. In Muzins, A. I. (ed.): Regionalnaya Geomorpholigiya Rayonov Novogo Osvoeniya, 83-98. Geographical Society of the USSR, Moscow (in Russian).

Lloyd, A., Yoshikawa, K., Fastie, C., Hinzman, L. \& Fraver, M. 2003: Effects of permafrost degradation on woody vegetation at arctic treeline on the Seward Peninsula, Alaska. Permafrost and Periglacial Processes 14, 93-102.

Lozhkin, A., Anderson, P., Matrosova, T. \& Minyuk, P. 2007: The pollen record from El'gygytgyn Lake: implications for vegetation and climate histories of northern Chukotka since the late middle Pleistocene. Journal of Paleolimnology 37, 135-153.

Melles, M., Brigham-Grette, J., Glushkova, O., Minyuk, P., Nowaczyk, N. \& Hubberten, H. 2007: Sedimentary geochemistry of core PG1351 from Lake El'gygytgyn - a sensitive record of climate variability in the East Siberian Arctic during the past three glacia1-interglacial cycles. Journal of Paleolimnology 37, 89-104.

Meyers, P. A. \& Ishiwatari, R. 1993: Lacustrine organic geochemistry - an overview of indicators of organic matter sources and diagenesis in lake sediments. Organic Geochemistry 20, 867-900.

Müller, M. J. 1980: Handbuch ausgewählter Klimastationen der Erde. Forschungsstelle Bodenerosion. Universität Trier, Mertesdorf.

Müller, S., Tarasov, P., Andreev, A. \& Diekmann, B. 2009: Late Glacial to Holocene environments in the present-day coldest region of the Northern Hemisphere inferred from a pollen record of Lake Billyakh, Verkhoyansk Mts, NE Siberia. Climate of the Past 5, 73-84.

Nott, C. J., Xie, S., Avsejs, L. A., Maddy, D., Chambers, F. M. \& Evershed, R. P. 2000: n-Alkane distributions in ombrotrophic mires as indicators of vegetation change related to climatic variation. Organic Geochemistry 31, 231-235.

Nowaczyk, N., Melles, M. \& Minyuk, P. 2007: A revised age model for core PG1351 from Lake El'gygytgyn, Chukotka, based on magnetic susceptibility variations correlated to northern hemisphere insolation variations. Journal of Paleolimnology 37, 65-76.

Popp, S., Diekmann, B., Meyer, H., Siegert, C., Syromyatnikov, I. \& Hubberten, H.-W. 2006: Palaeoclimate signals as inferred from stable-isotope composition of ground ice in the Verkhoyansk Foreland, Central Yakutia. Permafrost and Periglacial Processes 17, 119-132.

Reille, M. 1992: Pollen et Spores D'Europe et D'Afrique du Nord. Laboratoire de Botanique Historique et Palynologie. 543 pp. Laboratoire de Botanique historique et Palynologie, Marseille.

Reille, M. 1998: Pollen et Spores D'Europe et D'Afrique du Nord. Supplement 2. Laboratoire de Botanique Historique et Palynologie. 530 pp. Laboratoire de botanique historique et palynologie, Marseille.

Schwark, L., Zink, K. \& Lechtenbeck, J. 2002: Reconstruction of postglacial to early Holocene vegetation history in terrestrial Central Europe via cuticular lipid biomarkers and pollen records from lake sediments. Geology 30, 463-466.

Sher, A. V., Kuzmina, S. A., Kuznetsova, T. V. \& Sulerzhitsky, L. D. 2005: New insights into the Weichselian environment and climate of the East Siberian Arctic, derived from fossil insects, plants, and mammals. Quaternary Science Reviews 24, 533-569.

Stauch, G. \& Gualtieri, L. M. 2008: Late Quaternary glaciations in northeastern Russia. Journal of Quaternary Science 23, 545-558.

Stauch, G., Lehmkuhl, F. \& Frechen, M. 2007: Luminescence chronology from the Verkhoyansk Mountains (North-Eastern Siberia). Quaternary Geochronology 2, 255-259.

Svendsen, J. I., Alexanderson, H., Astakhov, V. I., Demidov, I., Dowdeswell, J. A., Funder, S., Gataullin, V., Henriksen, M., Hjort,
C. \& Houmark-Nielsen, M. 2004: Late Quaternary ice sheet history of northern Eurasia. Quaternary Science Reviews 23, 1229-1271.

Tarasov, P., Bezrukova, E. \& Krivonogov, S. 2009: Late Glacial and Holocene changes in vegetation cover and climate in southern Siberia derived from a $15 \mathrm{kyr}$ long pollen record from Lake Kotokel. Climate of the Past Discussions 5, 127-151.

Tarasov, P. E., Webb, T., Andreev, A. A., Afanas'eva, N. B., Berezina, N. A., Bezusko, L. G., Blyakharchuk, T. A., Bolikhovskaya, N. S., Cheddadi, R., Chernavskaya, M. M., Chernova, G. M., Dorofeyuk, N. I., Dirksen, V. G., Elina, G. A., Filimonova, L. V., Glebov, F. Z., Guiot, J., Gunova, V. S., Harrison, S. P., Jolly, D., Khomutova, V. I., Kvavadze, E. V., Osipova, I. M., Panova, N. K., Prentice, I. C., Saarse, L., Sevastyanov, D. V., Volkova, V. S. \& Zernitskaya, V. P. 1998: Present-day and mid-Holocene biomes reconstructed from pollen and plant macrofossil data from the former Soviet Union and Mongolia. Journal of Biogeography 25, 1029-1053.

Timofeev, P. 2003: Trees and shrubs in Yakutia. 193 pp. Publishing House 'Bichik', Yakutsk (in Russian).

Wein, N. 1999: Sibirien. 248 pp. Klett Partner, Gotha.

Werner, K., Tarasov, E., Andreev, A., Müller, S., Kienast, F., Zech, M., Zech, W. \& Diekmann, B. 2009: A 12.5-kyr history of vegetation dynamics and mire developement with evidence of Younger Dryas larch presence in the Verkhoyansk Mountains, East Siberia, Russia. Boreas, doi: 10.1111/j.1502-3885.2009.00116.x.

Wiesenberg, G. L. B., Schwarzbauer, J., Schmidt, M. W. I. \& Schwark, L. 2004: Source and turnover of organic matter in agricultural soils derived from n-alkane/n-carboxylic acid compositions and C-isotope signatures. Organic Geochemistry 35, 1371-1393.

Willis, K. \& Andel, T. 2004: Trees or no trees? The environments of central and eastern Europe during the Last Glaciation. Quaternary Science Reviews 23, 2369-2387.

Zech, M. 2006: Evidence for Late Pleistocene climate changes from buried soils on the southern slopes of Mt. Kilimanjaro, Tanzania. Palaeogeography, Palaeoclimatology, Palaeoecology 242, 303-312.

Zech, M. \& Glaser, B. 2008: Improved compound-specific $\delta^{13} \mathrm{C}$ analysis of n-alkanes for application in palaeoenvironmental studies. Rapid Communications in Mass Spectrometry 22, 135-142.

Zech, M., Zech, R. \& Glaser, B. 2007: A 240,000-year stable carbon and nitrogen isotope record from a loess-like palaeosol sequence in the Tumara Valley, Northeast Siberia. Chemical Geology 242, 307-318.

Zech, M., Zech, R., Zech, W., Glaser, B., Brodowski, S. \& Amelung, W. 2008: Characterisation and palaeoclimate of a loess-like permafrost palaeosol sequence in NE Siberia. Geoderma 143, 281-295.

Zech, M., Zech, R., Morrás, H., Moretti, L., Glaser, B. \& Zech, W. 2009: Late Quaternary environmental changes in Misiones, subtropical NE Argentina, deduced from multi-proxy geochemical analyses in a palaeosol-sediment sequence. Quaternary International 196, 121-136.

Zech, M., Buggle, B., Leiber, K., Markovic, S., Glaser, B., Hambach, U., Huwe, B., Stevens, T., Sümegi, P., Wiesenberg, G. \& Zöller, L. in press: Reconstructing Quaternary vegetation history in the Carpathian Basin, SE Europe, using n-alkane biomarkers as molecular fossils: problems and possible solutions, potential and limitations. Eiszeitalter and Gegenwart-Quaternary Science Journal.

Zhang, Z., Zhao, M., Yang, X., Wang, S., Jiang, X., Oldfield, F. \& Eglinton, G. 2004: A hydrocarbon biomarker record for the last 40 kyr of plant input to Lake Heqing, southwestern China. Organic Geochemistry 35, 595-613.

Zimov, S., Schuur, E. \& Chapin III, F. 2006: Permafrost and the Global Carbon Budget. Science 312, 1612-1613. 